\title{
H3K9me3 Inhibition Improves Memory, Promotes Spine Formation, and Increases BDNF Levels in the Aged Hippocampus
}

\author{
Shikha Snigdha, ${ }^{1}$ G. Aleph Prieto, ${ }^{1}$ Arpine Petrosyan, ${ }^{1}$ Brad M. Loertscher, ${ }^{2}$ André P. Dieskau, ${ }^{2}$ Larry E. Overman, ${ }^{2}$ \\ and Carl W. Cotman ${ }^{1}$ \\ ${ }^{1}$ Institute for Memory Impairments and Neurological Disorders and ${ }^{2}$ Department of Chemistry, University of California-Irvine, Irvine, California 92697
}

\begin{abstract}
An increasing number of studies show that an altered epigenetic landscape may cause impairments in regulation of learning and memory-related genes within the aged hippocampus, eventually resulting in cognitive deficits in the aged brain. One such epigenetic repressive mark is trimethylation of $\mathrm{H} 3 \mathrm{~K} 9$ ( $\mathrm{H} 3 \mathrm{~K} 9 \mathrm{me} 3$ ), which is typically implicated in gene silencing. Here, we identify, for the first time, an essential role for $\mathrm{H} 3 \mathrm{~K} 9 \mathrm{me} 3$ and its histone methyl transferase (SUV39H1) in mediating hippocampal memory functions. Pharmacological inhibition of SUV39H1 using a novel and selective inhibitor decreased levels of $\mathrm{H} 3 \mathrm{~K} 9 \mathrm{me} 3$ in the hippocampus of aged mice, and improved performance in the objection location memory and fear conditioning tasks and in a complex spatial environment learning task. The inhibition of SUV39H1 induced an increase in spine density of thin and stubby but not mushroom spines in the hippocampus of aged animals and increased surface GluR1 levels in hippocampal synaptosomes, a key index of spine plasticity. Furthermore, there were changes at BDNF exon I gene promoter, in concert with overall BDNF levels in the hippocampus of drug-treated animals compared with control animals. Together, these data demonstrate that SUV39H1 inhibition and the concomitant H3K9me3 downregulation mediate gene transcription in the hippocampus and reverse age-dependent deficits in hippocampal memory.
\end{abstract}

Key words: ETP69; H3k9me3; memory; synaptic function; aging; SUV39H1

\section{Significance Statement}

Cognitive decline is a debilitating condition associated with not only neurodegenerative diseases but also aging in general. However, effective treatments have been slow to emerge so far. In this study, we demonstrate that epigenetic regulation of key synaptic proteins may be an underlying, yet reversible, cause of this decline. Our findings suggest that histone 3 trimethylation is a probable target for pharmacological intervention that can counteract cognitive decline in the aging brain. Finally, we provide support to the hypothesis that, by manipulating the enzyme that regulates $\mathrm{H} 3 \mathrm{~K} 9 \mathrm{me} 3$ (using a newly developed specific inhibitor of SUV39H1), it is possible to alter the chromatin state of subjects and restore memory and synaptic function in the aging brain.

\section{Introduction}

Learning and memory decline with age as a consequence of multiple different mechanisms, many of which target the hippocampus. A growing body of evidence suggests that epigenetic regulation of genes and proteins is fundamental to these age-related changes in the

\footnotetext{
Received July 15, 2015; revised Jan. 21, 2016; accepted Jan. 30, 2016.

Author contributions: S.S. and C.W.C. designed research;S.S., G.A.P., and A.P. performed research; B.M.L., A.P.D., and L.E.O. contributed unpublished reagents/analytic tools; S.S. and G.A.P. analyzed data; S.S., G.A.P., and C.W.C. wrote the paper.

This work was supported in part by National Institute of Aging Grants AG012694-16, AG000538, and AG034667. A.P.D. was supported by the German Academic Exchange Service. B.M.L. was supported by National Cancer Institute 1F32CA180741 postdoctoral fellowship.

The authors declare no competing financial interests.

Correspondence should be addressed to Dr. Shikha Snigdha, University of California-Irvine, Irvine, CA 92697. E-mail: ssnigdha@uci.edu.

DOI:10.1523/JNEUROSCI.2693-15.2016

Copyright $\odot 2016$ the authors $\quad 0270-6474 / 16 / 363611-12 \$ 15.00 / 0$
}

hippocampus. In the context of aging and neurodegenerative conditions, histone acetylation has been extensively studied and is unmistakably associated with facilitating learning and memory (Mai et al., 2009; Gräff et al., 2012). On the other hand, changes in histone methylation states in the brain, relative to cognitive functions, is a relatively unexplored area of research (Gupta et al., 2010; Jarome and Lubin, 2014; Morse et al., 2015). Methylation of the histone tail typically occurs at specific lysine $(\mathrm{K})$ residues, such as $\mathrm{H} 3 \mathrm{~K} 4, \mathrm{H} 3 \mathrm{~K}$, $\mathrm{H} 3 \mathrm{~K} 27, \mathrm{H} 3 \mathrm{~K} 36, \mathrm{H} 3 \mathrm{~K} 79$, and H4K20, and can either activate or repress transcription (Vakoc et al., 2006). In particular, trimethylation of $\mathrm{H} 3 \mathrm{~K} 9$ (H3K9me3) is an important repressive histone mark, mainly involved in the formation and maintenance of silent heterochromatin state.

Several studies point to a pivotal role of $\mathrm{H} 3 \mathrm{~K} 9 \mathrm{me} 3$ in aging, including vascular inflammation and diabetes (Sedivy et al., 2008; Villeneuve et al., 2008, 2010). More recently, in an elegant 


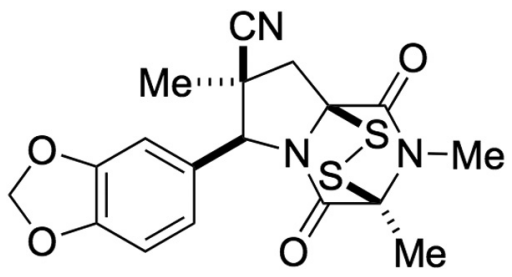

ETP69

Figure 1. Structure of ETP69 (Rac-(35,65,75,8aS)-6-(benzo[d][1,3]dioxol-5-yl)-2,3,7-trimethyl1,4-dioxohexahydro-6H-3,8a-epidithiopyrrolo[1,2-a]pyrazine-7-carbonitrile).

new study, Zhang et al. (2015b) also demonstrate how alterations in the heterochromatin state may drive human aging. The histone methyl transferase suppressor of variegation 3-9 homolog 1 (SUV39H1) is the principle enzyme responsible for the trimethylation of H3K9 (Stewart et al., 2005), and Zhang et al. (2015b) demonstrate how knockdown of SUV39H1 leads to a reduction of both overall $\mathrm{H} 3 \mathrm{~K} 9 \mathrm{me} 3$ and induction of cellular senescence. However, to date, there has not been any study that directly addresses the effect of SUV39H1 inhibition and the corresponding downregulation of $\mathrm{H} 3 \mathrm{~K} 9 \mathrm{me} 3$ on memory and cognitive function in the aging brain. Recent progress in the development of smallmolecule inhibitors of methyltransferases is a powerful means to change this.

In this study, we investigated, for the first time, the role of $\mathrm{H} 3 \mathrm{~K} 9 \mathrm{me} 3$ in learning and memory in aged mice treated with the SUV39H1 inhibitor ETP69, a newly developed analog of the epidithiodiketopiperazine alkaloid chaetocin A, the first reported inhibitor of SUV39H1 (Fig. 1) (Greiner et al., 2005; Cherblanc et al., 2013; Overman et al., 2014; Baumann et al., 2015). ETP69, initially developed for use in cancer treatment, shows significantly greater selectivity against a panel of 17 human histone methytransferases than chaetocin A, and exhibits no inhibitory activity toward histone acetyltransferase p300 and DNA methyltransferase DNMT1 (Overman et al., 2014). It is well accepted that hippocampal impairments result in severe deficits in spatial memory (Duva et al., 1997; Bachevalier and Nemanic, 2008). Accordingly, we used a spatial memory task (object location memory task), known to be hippocampal dependent, to evaluate the effects of $\mathrm{H} 3 \mathrm{~K} 9 \mathrm{me} 3$ manipulation in aged animals. This test has been used extensively to evaluate novel compounds for their effects on cognitive deficits (Haettig et al., 2011; Intlekofer et al., 2013). In addition, we used the fear conditioning task and a spontaneous activity task, referred to as the unsupervised learning (USL) task, to extend and confirm our findings. The USL and fear conditioning tasks both measure hippocampal-dependent learning, and the USL task is known to be highly correlated with synaptic changes in the hippocampus (Cox et al., 2014), and are susceptible to age-related deficits.

Then to identify the downstream regulatory mechanisms underlying memory improvements by $\mathrm{H} 3 \mathrm{~K} 9 \mathrm{me} 3$ inhibition, we evaluated cellular/molecular events, including epigenetic and protein changes on BDNF and synapse growth. We identified the effect of ETP69 on hippocampal spine formation using Golgi staining and flow synaptometry, a new method that can be used to profile synapses using isolated synaptosomes (Prieto et al., 2015). Overall, our data reveal that ETP69 has procognitive benefits for the aging brain and that this effect supports a role of $\mathrm{H} 3 \mathrm{~K} 9 \mathrm{me} 3$ in memory function.

\section{Materials and Methods}

Animals

Aged (18-20 months, $n=48$ ) or young (3-4 months, $n=18$ ) C57BL/6J male mice were group housed with food and water ad libitum and were acclimated to the vivarium for 1 week before experimental procedures. Lights were maintained on a 12:12 light/dark cycle, and all behavior testing was performed during the light phase of the cycle.

\section{Compound}

ETP69 (Rac-(3S,6S,7S,8aS)-6-(benzo[d] [1,3] dioxol-5-yl)-2,3,7-trimethyl1,4-dioxohexahydro-6 $\mathrm{H}$-3,8a-epidithiopyrrolo[1,2-a]pyrazine-7-carbonitrile) is a racemic analog of epidithiodiketopiperazine alkaloids, such as chaetocin A, and was prepared as described previously (Overman et al., 2014) and recrystallized from methanol. Compound was dissolved in a mixture of 50\% DMSO-based saline solution. Control subjects received DMSO saline solution.

\section{Testing}

Object location memory (OLM) task. Training and testing procedures were performed using a standard OLM protocol. Briefly, 22 aged mice and 18 young mice were handled for $\sim 2-3$ min per day for $5 \mathrm{~d}$, followed by habituation to the experimental apparatus (white rectangular open field measuring $30 \times 23 \times 21.5 \mathrm{~cm}$ ) for $5 \mathrm{~min}$ per day for 5 consecutive days before training.

Dose-response in OLM. On the test day, mice were given $3 \mathrm{~min}$ of habituation (in an empty test arena) followed by a single intraperitoneal injection of ETP69 $(10 \mathrm{mg} / \mathrm{kg}, n=8$; or $20 \mathrm{mg} / \mathrm{kg}, n=7$; or vehicle, $n=$ 7). Mice were then given a 3 min acquisition trial (with 2 similar objects placed in the arena opposite each other) $30 \mathrm{~min}$ after the injection of drug or vehicle, and all animals were then returned to their home cages for a $24 \mathrm{~h}$ intertrial interval. Twenty-four hours later, a 3 min retention test was administered, where one object was moved to a novel location and the amount of time the animals spent exploring the novel versus familiar location was recorded to evaluate the dose-response in the OLM task. Because animals that had received $10 \mathrm{mg} / \mathrm{kg}$ performed better than other groups in the OLM task, we used $10 \mathrm{mg} / \mathrm{kg}$ for the remainder of the study. This OLM paradigm has previously been shown to be subthreshold for learning (Stefanko et al., 2009; Intlekofer et al., 2013). Locomotor activity was also measured in this paradigm using the line crossings method (Snigdha et al., 2011).

Acquisition (pretraining) or consolidation (post-training). In another test, aimed to determine the efficacy of the compound in pretraining and post-training paradigms, the same group of 22 aged animals was retested on the OLM task 3 weeks after the first test. To determine whether the drug impacted acquisition or consolidation mechanisms, mice were injected (i.p.) with $10 \mathrm{mg} / \mathrm{kg}$ compound $(n=7)$ or vehicle $(n=8)$ either right before or after acquisition phase. At $24 \mathrm{~h}$ later, animals were killed after retention testing, and hippocampi were removed, rapidly frozen on dry ice, and stored at $-80^{\circ} \mathrm{C}$ until processing for trimethylation levels and BDNF assay.

Eighteen young mice were also tested in the same OLM paradigm as described above. To determine whether the drug impacted acquisition or consolidation mechanisms, the young mice were injected with the 10 $\mathrm{mg} / \mathrm{kg}$ compound or vehicle (i.p., $n=6 /$ group) either just before or right after the acquisition trial, and tested $24 \mathrm{~h}$ after acquisition.

USL. A new group of 12 aged animals were used for the unsupervised learning task. Procedures were adapted from published work (Fedulov et al., 2007; Chen et al., 2010a, b). The USL behavioral apparatus consisted of a large open field divided by walls into 4 chambers, all accessible by small entrances in each dividing wall (see Fig. $5 a$ ). The animals can also access a smaller attached enclosed dark compartment by an open entrance. After $5 \mathrm{~d}$ of handling, animals were injected with ETP69 (10 $\mathrm{mg} / \mathrm{kg}$, i.p.) or vehicle and placed in the video-monitored USL box for 30 $\mathrm{min}$, and then returned to the home cage. At $24 \mathrm{~h}$ later, the animals were placed in the USL box again and killed immediately afterward. Their brains were rapidly removed, hippocampus dissected rapidly, frozen on dry ice, and stored at $-80^{\circ} \mathrm{C}$ until further processing.

Contextual fear conditioning. Fourteen aged (18-20 months) male mice were placed in the fear-conditioning chamber and allowed to ex- 
a

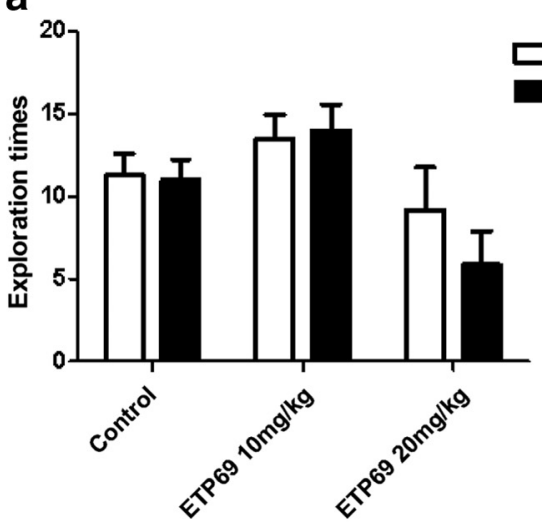

C

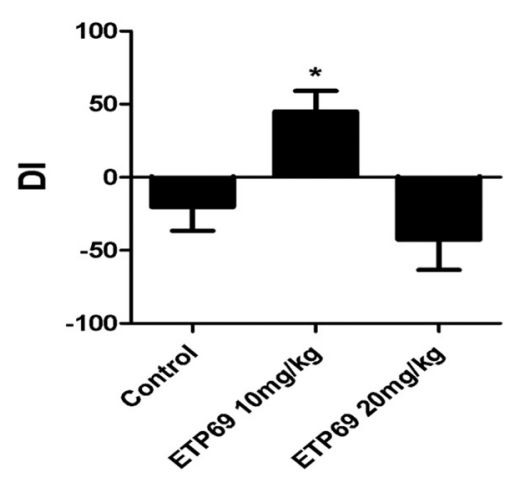

b

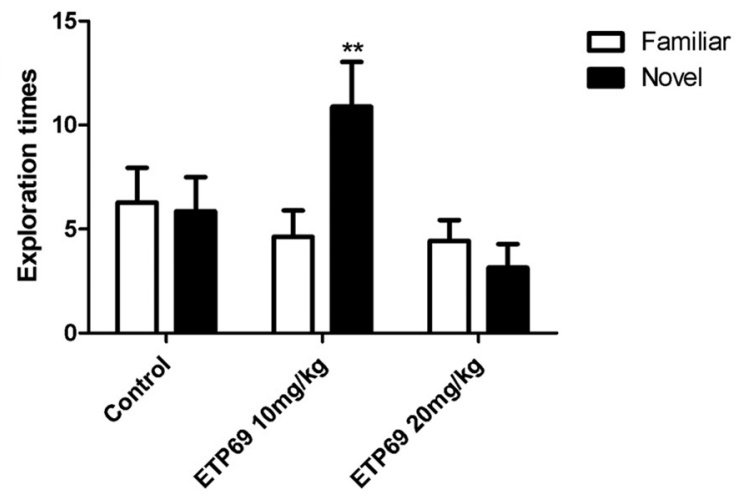

d

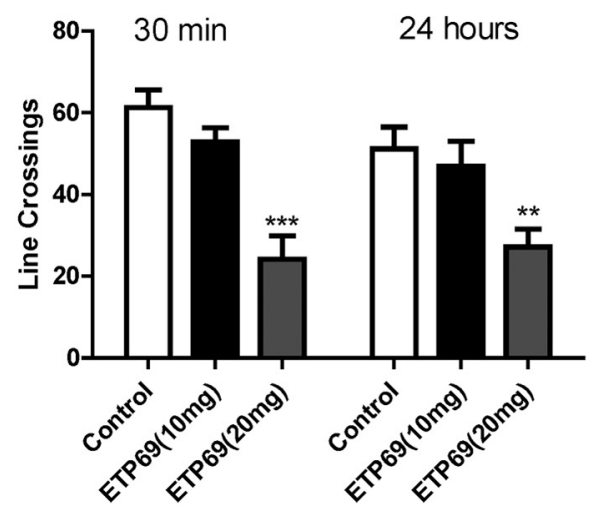

Figure 2. a, Mice treated with ETP69 at $10 \mathrm{mg} / \mathrm{kg}$ and $20 \mathrm{mg} / \mathrm{kg}$ (i.p.) administered $30 \mathrm{~min}$ before acquisition phase in the $0 \mathrm{LM}$ showed no difference in object exploration (measured in seconds) in the acquisition phase. Data are mean \pm SEM; $n=7$ or $8 /$ group. $\boldsymbol{b}$, In the retention phase of the task ( $24 \mathrm{~h}$ after drug administration) mice treated with $10 \mathrm{mg} / \mathrm{kg}$ of ETP69 (i.p.) explored the novel object significantly (measured in seconds) more than the familiar object ( ${ }^{* *} p \leq 0.01$, Bonferroni $t$ test). Mice treated with $20 \mathrm{mg} / \mathrm{kg}$ of ETP69 performed similar to aged controls. Data are mean \pm SEM; $n=7$ or 8/group. c, Effect of ETP69 treatment on discrimination index in aged animals. Mice treated with $10 \mathrm{mg} / \mathrm{kg}$ of ETP69 (i.p.) showed improved discrimination index [time spent at novel object location - time spent at familiar object location]/[total time exploring both objects $\times 100$ ] compared with aged controls. ${ }^{*} p<0.05$ (Bonferroni $t$ test). Data are mean \pm SEM; $n=7$ or 8/group. $\boldsymbol{d}$, Effect of ETP69 treatment on locomotor activity (measure by line crossings) in aged animals. Mice treated with $20 \mathrm{mg} / \mathrm{kg}$ (but not $10 \mathrm{mg} / \mathrm{kg}$ ) of the compound showed significant reduction in locomotor activity compared with aged control. ${ }^{* *} p<0.01,{ }^{* * *} p<0.001$ (Bonferroni $t$ test). Data are mean \pm SEM; $n=7$ or $8 /$ group.

plore for $2 \mathrm{~min}$ before receiving one electric foot shocks $(2 \mathrm{~s}, 0.2 \mathrm{~mA})$. Animals were returned to the home cage 2 min after the foot shock. Twenty-four hours later, behavior in the conditioning chamber was observed for $5 \mathrm{~min}$ and subsequently was analyzed for freezing behavior, which was defined as the absence of all movement except for respiration.

Histone trimethylation. Total histone was extracted from frozen hippocampi of 3 young and 3 old mice using an EpiQuik extraction kit (OP-0006-100) following the manufacturer's protocol. In brief, tissue was weighed and cut into small pieces and homogenized in $1 \times$ prelysis buffer, transferred in a $2 \mathrm{ml}$ tube, and centrifuged at 10,000 $\times g$ for $1 \mathrm{~min}$ at $4^{\circ} \mathrm{C}$. The supernatant was removed; tissue pellet was resuspended in 3 volumes of lysis buffer, incubated on ice for $30 \mathrm{~min}$, and centrifuged at $12,000 \times g$ for $5 \mathrm{~min}$ at $4^{\circ} \mathrm{C}$. Balance-DTT buffer ( 0.3 volumes) was added to the supernatant, which was stored at $-80^{\circ} \mathrm{C}$. The protein concentration of the eluted histone was estimated using a Bradford protein detection kit (Bio-Rad) using BSA as a standard. Histone (H3K9) trimethylation analysis was performed according to the manufacturer's information (ab115064). Briefly, trimethylated histones were captured using specific antibody and detected with a labeled detection antibody, followed by a color development reagent. Absorbance was read at 450 $\mathrm{nm}$, and results were calculated using a standard curve following the manufacturer's instructions.

Spine counts. In another series of experiments, 12 aged mice (20-22 months) were injected with ETP69 (10 mg/kg; i.p) or vehicle (i.p.); and $24 \mathrm{~h}$ later, the animals were killed, and the brains were separated into two hemispheres. The right hemisphere was used for Golgi staining, and the left was processed for flow synaptometry. Staining was conducted according to the manufacturer's information (Golgi-Cox, Bioenna), and spine densities were calculated relative to the 3D length of the sampled segments of stained dendrites.

Flow synaptometry. Fresh synaptosome P2 fractions were obtained from whole-mouse hippocampus using our long-standing protocol (Sandoval et al., 1978). Briefly, the fractions were obtained from the hippocampas by homogenizing tissue $(1: 10 \mathrm{w} / \mathrm{v})$ in ice-cold sucrose 320 $\mathrm{mm}$. All the steps were performed at $4^{\circ} \mathrm{C}$; sucrose buffer, grinder, pestle, and microfuge tubes were all precooled on ice. Hippocampi were rapidly dissected form a single mouse and homogenized in $320 \mathrm{~mm}$ sucrose (1.5 $\mathrm{ml}$ ) containing HEPES $(10 \mathrm{~mm})$ and a protease/phosphatase inhibitor mixture (Pierce), $\mathrm{pH}$ 7.4. Homogenization consisted of 6-8 manual strokes in a glass-Teflon grinder, clearance (between plunger and glass): $0.15-0.25 \mathrm{~mm}$. The plunger was gently rotated during strokes while the grinder was kept on ice. The homogenate was centrifuged at $1200 \times g$ for $10 \mathrm{~min}$. Supernatant (S1, containing mitochondria and synaptosomes) was transferred into two clean microfuge tubes and centrifuged at $12,000 \times g$ for $20 \mathrm{~min}$. Supernatants (S2) were carefully removed using a plastic tip and vacuum. Pellets (P2, corresponding to the crude synaptosome fraction) were resuspended by gently pipetting up and down in $1.5 \mathrm{ml}$ of PBS. Protein concentration was determined using the BCA assay using BSA as standard. Before immunolabeling, we adjusted all samples to the same protein concentration using PBS as diluent. Immunolabeling for flow synaptometry analysis was performed according to a method for staining of extracellular/intracellular antigens using $200 \mu \mathrm{l}$ of synaptosomal fractions (50-100 $\mu \mathrm{g}$ protein). Antibodies included the following: GluR1 (extracellular) (Millipore, ABN241, DIL = 1:400), pAkt-ser473 (Cell Signaling Technology, 4060, DIL = 1:400), PSD95 (Millipore, MAB1598, DIL = 1:400), anti-rabbit IgG Alexa-488 and anti- 
a

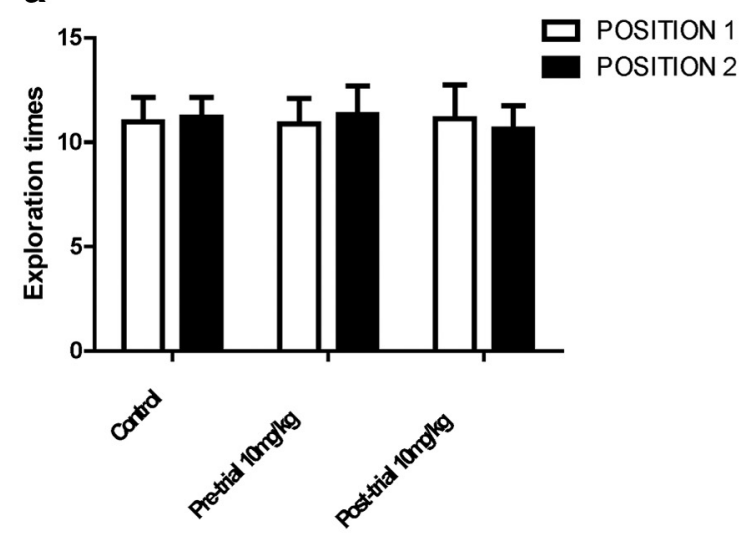

b

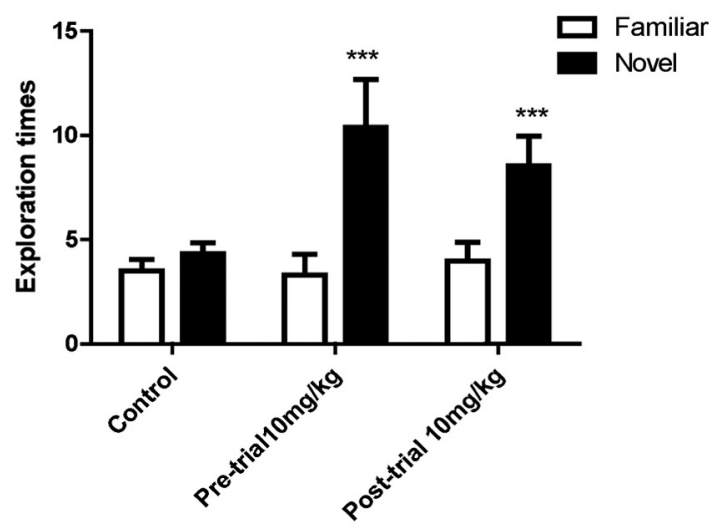

C

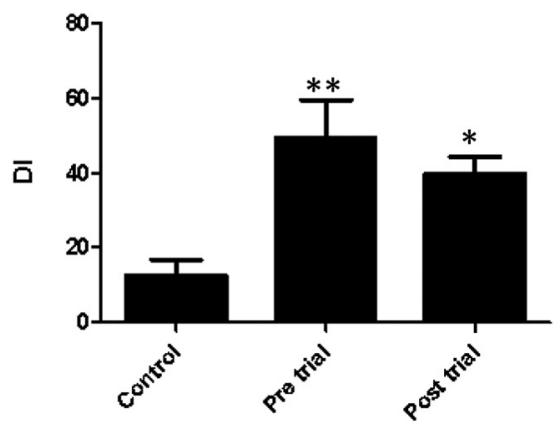

Figure 3. $a$, Effect of the drug at $10 \mathrm{mg} / \mathrm{kg}$ (i.p.) administered either $30 \mathrm{~min}$ before acquisition phase (pre-trial) or immediately after acquisition (post-trial) in the object location memory task in aged mice. No difference in object exploration (measured in seconds) in the acquisition phase. Data are mean \pm SEM. Pre-trial, $n=6 /$ group; post-trial, $n=8 /$ group. $\boldsymbol{b}$, In the retention phase of the task (24 h $\pm 30 \mathrm{~min}$, after drug administration), mice treated with $10 \mathrm{mg} / \mathrm{kg}$ of ETP69 (i.p.) explored the novel location (measured in seconds) significantly more than the familiar location. ${ }^{* * *} p<0.001$ (Bonferroni $t$ test). Data are mean \pm SEM. Pre-trial, $n=6 /$ group; post-trial, $n=8 /$ group. $c$, Effect of ETP69 treatment on discrimination index in aged animals either 30 min before acquisition phase (pre-trial) or immediately after acquisition (post-trial). Mice treated with $10 \mathrm{mg} / \mathrm{kg}$ of ETP69 (i.p.) showed improved discrimination index [time spent at novel object location time spent at familiar object location]/[total time exploring both objects $\times 100$ ] compared with aged control in both conditions. ${ }^{*} p<0.05$ (Bonferroni $t$ test). ${ }^{* *} p<0.01$ (Bonferroni $t$ test). Data are mean $\pm \mathrm{SEM} ; n=7$ or $8 /$ group.

mouse IgG Alexa 647 (Invitrogen, DIL = 1:400). Data were acquired using a FACS Calibur flow cytometer (BD Biosciences) equipped with argon $488 \mathrm{~nm}$ and helium-neon $635 \mathrm{~nm}$ lasers. Relative size and granularity were determined by forward (FSC) and side scatter (SSC) properties. FSC, SSC, FL1, and FL4 signals were collected using log amplification. Alexa- 488 and Alexa- 647 fluorochromes were detected by the FL1 and FL4 detectors, respectively. FSC-SSC plots were used to select particles matching the size of synaptosomes $(0.5-3.0 \mu \mathrm{m})$ using calibrated beads (see Fig. 9a), as previously described (Fein et al., 2008). Identical FSC settings were used for acquiring data on bead standards and samples. Small fragments and debris were excluded by establishing a FSC-H threshold (325). A total of 10,000 size-gated particles were collected and analyzed for each sample. Analysis was performed using the CellQuest Pro software (BD Biosciences).

ELISA. ELISA was performed using the BDNF Emax Immunoassay System (G7610, Promega) according to the manufacturer's instructions. Two sets of samples were prepared from the hippocampus of each animal, and all reactions were performed in duplicate.

In the first series of experiments, we had established that BDNF was a target of ETP69; then we used brains obtained from a second set of experiments (USL task) to detect which BDNF exons were methylated and which downstream targets of BDNF showed changes following ETP69 treatment.

ChIP for BDNF promoter regions. After cross-linking with $1 \%$ formaldehyde, chromatin was sheared to fragments of 200-500 bp. Immunoprecipitation was realized overnight at $4^{\circ} \mathrm{C}$ with an antibody directed against histone $\mathrm{H} 3 \mathrm{~K} 9 \mathrm{me} 3$ (Millipore). After washes, elution from beads, and reversal of the cross-link, immunoprecipitated DNA was purified and analyzed in triplicate by qRT-PCR with an internal standard curve prepared from pooled input samples. Each sample was normalized with the respective input value. Primers for $b d n f$ promoters for exon I, IV, and VI correspond to each unique exon sequence (Aid et al., 2007; Intlekofer et al., 2013). qRT-PCR primer sets were designed using the Roche Universal Probe Library Assay Design Center and obtained from Integrated DNA Technologies. qRT-PCR was run in a Stratagene MX3005P thermocycler at $95^{\circ} \mathrm{C}$ for $3 \mathrm{~min}$, followed by 45 cycles of $95^{\circ} \mathrm{C}$ for $10 \mathrm{~s}$ and $58^{\circ} \mathrm{C}$ for $15 \mathrm{~s}$. Each qRT-PCR run included all samples run in triplicate and a standard curve. Data were analyzed by the $2^{-\Delta \Delta \mathrm{Ct}}$ method and expressed as fold change over control after normalizing with input samples, as described previously (Sahar et al., 2007).

Statistical analysis. Mann-Whitney test was used as nonparametric $t$ test for paired and unpaired data, and Student's $t$ test were used for parametric data. One-way ANOVAs were followed by post hoc Tukey's test for mean comparisons of three or more groups; whereas two-way ANOVAs were followed by Bonferroni's post hoc test. All statistical tests and the nonlinear fit for Figure $9 b$ were performed using GraphPad Prism 6. Data are presented as mean \pm SEM. $p<0.05$ was considered significant.

\section{Results}

Acute administration of ETP69 improved performance of aged mice in the OLM task

We first conducted a dose-response study to test the effects of intraperitoneally administered ETP69 in the spatial OLM task. The dose range included amounts known to be well tolerated in mice (Overman et al., 2014). Our results show that $10 \mathrm{mg} / \mathrm{kg}$, but not $20 \mathrm{mg} / \mathrm{kg}$, of ETP69 induced memory improvements in the 
a

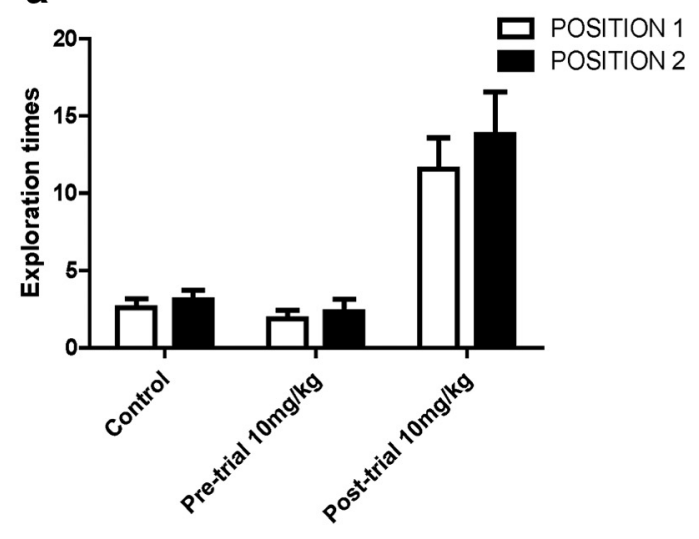

C

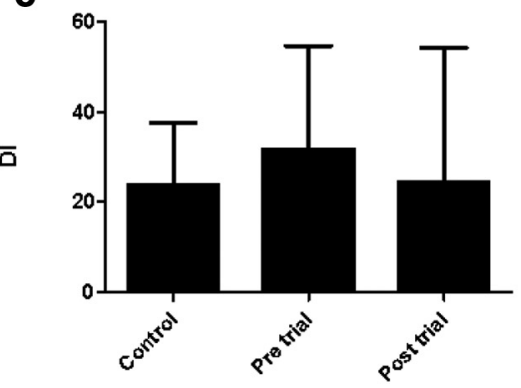

b

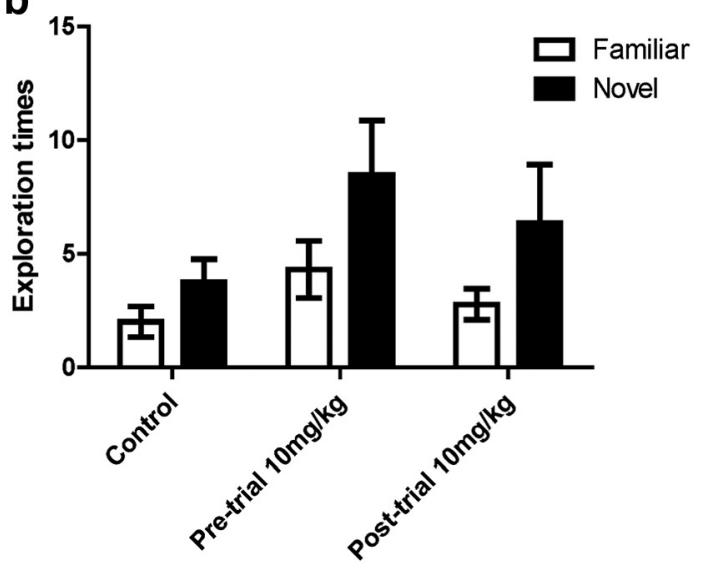

Figure 4. $\boldsymbol{a}$, Effect of the drug at $10 \mathrm{mg} / \mathrm{kg}$ (i.p.) administered either $30 \mathrm{~min}$ before acquisition phase (pre-trial) or immediately after acquisition (post-trial) in the object location memory task in young mice. No difference in object exploration (measured in seconds) in the acquisition phase. Data are mean \pm SEM; $n=6 / \mathrm{group}$. $\boldsymbol{b}$, In the retention phase of the task ( $24 \mathrm{~h} \pm 30 \mathrm{~min}$, after drug administration), drug-treated young animals did not show a preference for novel location (measured in seconds), performing similar to the young controls. Data are mean \pm SEM; $n=6 /$ group. c, Effect of ETP69 treatment on discrimination index in young animals. Mice treated with $10 \mathrm{mg} / \mathrm{kg}$ of ETP69 (i.p.) showed no improvement in discrimination index [time spent at novel object location - time spent at familiar object location] $/[$ total time exploring both objects $\times 100]$ compared with age-matched controls. Data are mean \pm SEM; $n=6 /$ group.

OLM task in aged mice (Fig. 2b,c). This was demonstrated using a two-way ANOVA (interaction effect: $F_{(2,19)}=10.25, p<0.01$; Fig. $2 b)$ on the exploration times, with post hoc testing showing that the group receiving $10 \mathrm{mg} / \mathrm{kg}$ of the drug performed significantly better compared with controls $(p<0.05)$, and further confirmed by one-way ANOVA of the discrimination index $\left(F_{(2,18)}=6.48\right)$ followed by post hoc testing $(p<0.05$; Fig. $2 c)$. The acquisition phase of the testing showed no significant interaction effect $\left(F_{(2,19)}=2.21, p=0.139\right.$; Fig. $\left.2 a\right)$ or main effect of object location $\left(F_{(1,19)}=1.83, p=0.19\right)$. However, there was a significant treatment effect $\left(F_{(2,19)}=3.18, p<0.05\right)$, with animals that had been given a higher dose of the drug $(20 \mathrm{mg} / \mathrm{kg})$ showing a decrease in total exploration time $(p<0.05)$. This suggests that higher doses of the H3K9me3 downregulation may impair overall exploration and possibly impair locomotor activity in aged animals. This was confirmed by measuring locomotor activity of animals (Fig. 2c). A two-way ANOVA on the locomotor activity levels showed no interaction effect $\left(F_{(2,18)}=1.22, p=\right.$ $0.31)$ or time effect $\left(F_{(1,18)}=1.16, p=0.213\right)$, but there was a significant effect of treatment $\left(F_{(2,18)}=14.2, p<0.01\right.$; Fig. $\left.2 d\right)$. Accordingly, we selected the lower dose for all further testing.

Next, we sought to determine whether ETP69 treatment differentially affects performance accuracy in the OLM task in a pre-trial versus a post-trial administration paradigm. The pretrial versus post-trial paradigms for the OLM task allow for testing of two distinct components of memory formation. Specifically, the pre-training drug administration evaluates acquisition and recall of memory, whereas the post-training drug administration targets memory consolidation and recall. Thus, we administered the drug either $30 \mathrm{~min}$ before or immediately after the acquisition phase of the OLM test. We found that 10 $\mathrm{mg} / \mathrm{kg}$ (i.p.) of the drug, administered either $30 \mathrm{~min}$ before acquisition phase or immediately after acquisition, improved performance in the OLM task (interaction effect: $F_{(2,19)}=9.81, p<$ 0.01 ; Fig. $3 b)$. Further post hoc testing showed a significant effect in both the pretrial and post-trial groups $(p<0.001)$. This was also confirmed by one-way ANOVA $\left(F_{(2,19)}=3.67\right)$ of the discrimination index $(p<0.01$ for pre-trial and $p<0.05$ for post trial; Fig. 3c) The acquisition phase of the testing showed no significant group differences (interaction: $F_{(2,19)}=0.26, p=$ 0.773; main effect of drug: $F_{(2,19)}=0.01, p=0.982$; main effect of object location: $F_{(1,19)}=0.01, p=0.901$; Figure $\left.3 a\right)$.

To test the hypothesis that $\mathrm{H} 3 \mathrm{~K} 9 \mathrm{me} 3$ inhibition positively impacts memory in young and aged mice, we extended the behavioral testing to young mice. Unlike in aged animals, administration of ETP69 did not improve OLM performance in young mice. The $10 \mathrm{mg} / \mathrm{kg}$ (i.p.) of the drug, administered either $30 \mathrm{~min}$ before acquisition phase (pre-trial) or immediately after acquisition (post-trial), did not show any statistical differences compared with young controls (interaction effect: $F_{(2,15)}=0.32, p=$ 0.728; main effect of drug: $F_{(2,15)}=2.21, p=0.143$; main effect of object location: $F_{(2,15)}=6.02, p<0.05$; Figure $\left.4 b\right)$. This was also confirmed by one-way ANOVA $\left(F_{(2,17)}=0.035\right)$ of the discrimination index (Fig. $4 c$ ). The acquisition phase of the testing also showed significant group differences (interaction: $F_{(2,15)}=0.44$, $p=0.652$; main effect of drug: $\left.F_{(2,15)}=25.01, p<0.01\right)$ in the pre-trial versus post-trial groups, but no difference between exploration of Position 1 versus Position 2 (main effect of object location: $F_{(2,15)}=1.56, p=0.229$; Fig. $\left.4 a\right)$. This suggests that 
a

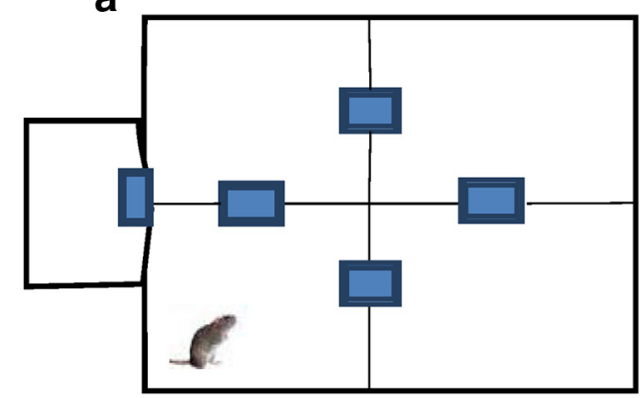

b

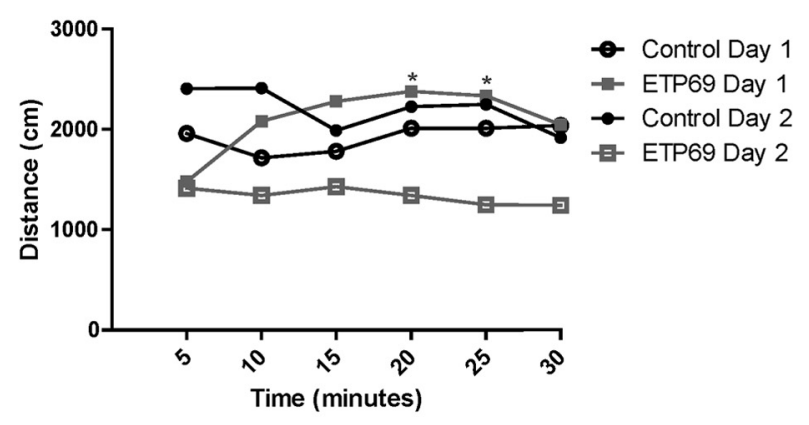

C

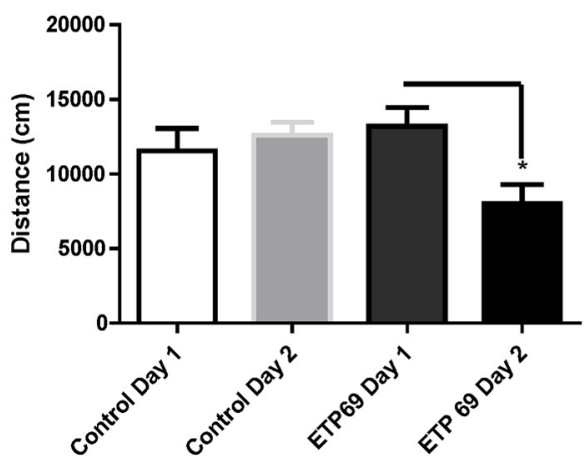

Figure 5. a, The unsupervised learning test arena is a large open field divided by walls into 4 chambers, all accessible by small entrances in each dividing wall, and a black box into which mice can escape. $\boldsymbol{b}$, Aged mice treated with ETP69 (10 mg/kg, i.p.) showed a significant decrease in habituation/exploration (as measured by distance traveled) on day 2 compared with day 1 . Aged control mice spent equal time(s) exploring the test arena on both day 1 and day 2 . Habituation was measured over 30 min, and data shown are in 5 min bins. ${ }^{*} p<0.05$, significant difference between habituation/exploration on day 1 and day 2 at the specified time points (Tukey's $t$ test). $n=5$ or $6 /$ group. $c$, Graph represents the total distance traveled over 30 min on day 1 and day 2 following administration of ETP69 (10 mg/kg, i.p) or vehicle. ${ }^{*} p<0.05$, significant decrease in total distance traveled in 30 min between day 1 and day 2 (Tukey's $t$ test). Data are mean $\pm \mathrm{SEM} ; n=5$ or $6 /$ group.

H3K9me3 manipulation may have quite different effects in the young versus aged brain.

\section{ETP69 administration improves performance in the USL task in aged animals}

To evaluate whether $\mathrm{H} 3 \mathrm{~K} 9 \mathrm{me} 3$ is implicated in measures of spatial learning and to evaluate molecular endpoints, we conducted a second series of experiments, with the USL task being the behavioral endpoint. The USL task is a simple behavioral paradigm in which mice are allowed to freely explore a four-compartment environment for a specified period of time. Reduction in overall activity and exploration of the test arena over this time is considered a measure of learning and short-term memory. If this occurs at similar rates in the two groups, it indicates no significant differences in short-term learning and the locomotor pattern of animals during this task is highly correlated with synaptic changes in the hippocampus (Cox et al., 2014).

During the test, well-handled mice were placed in the fourcompartment test box and their movements were monitored for $30 \mathrm{~min}$ on day 1 and then again $24 \mathrm{~h}$ later on day 2 . We found that animals treated with ETP69 (10 mg/kg, i.p.) showed a significant decrease in habituation/exploration (as measured by distance traveled) $24 \mathrm{~h}$ after treatment but not in the first $30 \mathrm{~min}$ on day 1 (Fig. 5b). One-way ANOVA revealed significant group differences $\left(F_{(3,19)}=4.05, p<0.05\right)$, and post hoc testing confirmed the difference between performance on day 1 and day 2 in ETP69treated animals $(p<0.05)$ but not in the age-matched control group (Fig. $5 c$ ). The $30 \mathrm{~min}$ of exploration on day 1 is sufficient to induce some long-term memory of the test arena in the mice and can be measured on day 2 of testing. We found a difference in activity levels on day 2 and interpret this as improved retention and recall in ETP69-treated animals, even when learning remains the same between groups.

\section{ETP69 administration improves performance in the} contextual fear conditioning task in aged animals

To confirm our findings from the OLM and USL tasks, we used the contextual fear conditioning to test the effect of $\mathrm{H} 3 \mathrm{~K} 9 \mathrm{me} 3$ downregulation on hippocampal-dependent learning and memory. We found that aged animals ( $n=7 /$ group) that had been treated with ETP69 showed improved performance on the task compared with aged controls $(p<0.01$; Fig. 6). Overall, these behavioral data suggest that ETP69 administration improves hippocampal-dependent learning and memory over a battery of tests.

\section{ETP69 administration decreases levels of $\mathrm{H} 3 \mathrm{~K} 9 \mathrm{me} 3$ in the hippocampus of aged mice}

We first compared $\mathrm{H} 3 \mathrm{~K} 9 \mathrm{me} 3$ levels in the hippocampus and cerebellum of young versus old mice and found significantly higher level of $\mathrm{H} 3 \mathrm{~K} 9 \mathrm{me} 3$ in aged mice in the hippocampus (Fig. 7a; $p<0.05$ ) but not in the cerebellum (Fig. 7b). The OLM and USL are both hippocampal-specific, and we found a difference in $\mathrm{H} 3 \mathrm{~K} 9 \mathrm{me} 3$ levels in the hippocampus of young versus old mice. Accordingly, we next tested the total level of $\mathrm{H} 3 \mathrm{~K} 9 \mathrm{me} 3$ in the hippocampus following drug treatment in hippocampal tissue samples from the cohort of animals described above in the OLM task. Our results showed a significant effect of the drug in histone extracts from the hippocampus of the drug-treated animals. Statistical analysis showed decreases in $\mathrm{H} 3 \mathrm{~K} 9 \mathrm{me} 3$ levels in aged animals treated with ETP69 $(p<0.05$, Fig. $7 c)$ but not in young animals (Fig. $7 d$ ). 


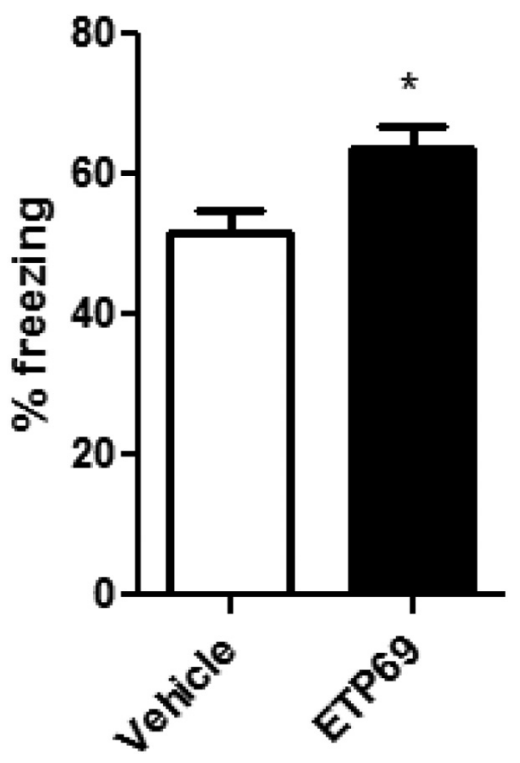

Figure 6. Aged mice treated with ETP69 (10 mg/kg, i.p.) showed improved performance when contextual fear conditioning was assessed. ${ }^{*} p=0.01$ (Bonferroni $t$ test). Data are mean $\pm \mathrm{SEM} ; n=7$ per group.

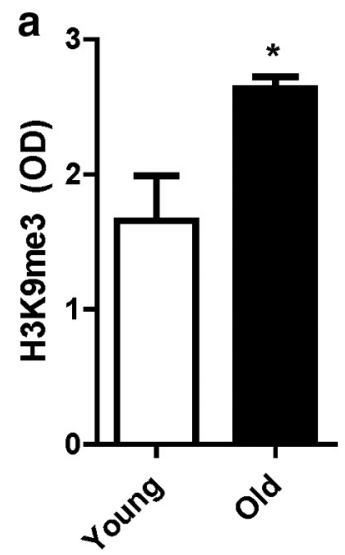

C

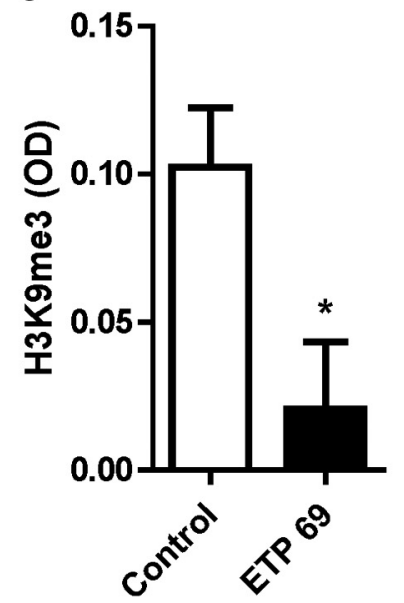

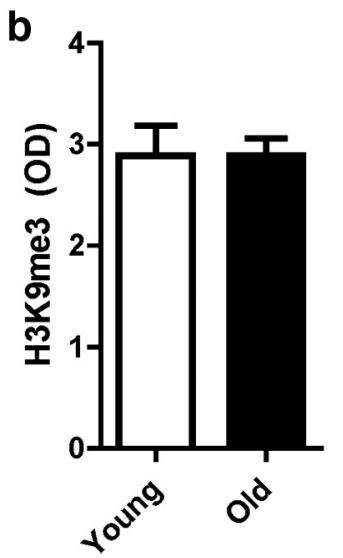

d

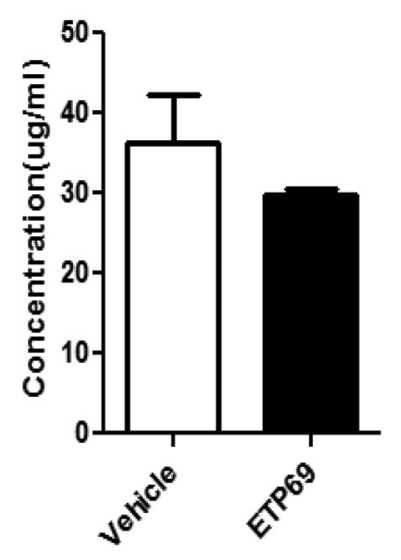

Figure 7. Trimethylation levels of H3K9 in (a) hippocampal extracts young versus aged mice and $(\boldsymbol{b})$ cerebellum extracts of young versus aged mice. $n=3$ /group. ${ }^{*} p<0.05$ (Student's unpaired $t$ test). Trimethylation levels of H3K9 in the hippocampus of (c) aged mice and (d) young mice, which received $10 \mathrm{mg} / \mathrm{kg}$ of ETP69 (i.p.) or vehicle, $24 \mathrm{~h}$ after drug administration. $n=7$ /group. ${ }^{*} p<0.05$ (Student's unpaired $t$ test).
In addition, we also evaluated the global levels of $\mathrm{H} 3 \mathrm{~K} 9 \mathrm{me} 2$ in aged mice, which has already been linked to learning and memory deficits (Balemans et al., 2013), but did not observe any significant effects of ETP69 treatment in aged mice $(p=$ 0.95 , unpaired $t$ test, data not shown).

\section{H3K9me3 inhibition increases spine density and GluR1} receptor surface expression in hippocampal synaptosomes It has been reported that novel memory formation can be associated with a transient increase in spine density in the hippocampus (Restivo et al., 2009). In particular, improved performance in the OLM (Babayan et al., 2012) and USL (Cox et al., 2014) tasks is associated with structural and/or functional changes at excitatory glutamatergic synapses Thus, we examined whether pharmacological inhibition of the histone methyltransferase (SUV39H1) was sufficient to induce an increase in dendritic spine formation in the hippocampus.

Specifically, using Golgi-stained sections, we counted and classified spines on CA1 pyramidal neurons. Dendrite segments from neurons in CA1 of the hippocampus were imaged by confocal microscopy, and a blinded investigator counted and classified dendritic spines according to their morphology. Spines were manually counted and classified as thin, mushroom, or stubby, according to previously described criteria (Harris et al., 1992).

For each animal, at least 5 pyramidal neurons and $200 \mu \mathrm{m}$ of total dendrite length and 250-500 spines were analyzed $(n=6$ animals per group). All of the neurons were chosen from the dorsal part of the CA1 hippocampal region (according to its essential role in spatial memory) and were completely stained along basal and apical dendrites (Fig. 8b). Segregation analysis based on anatomically observed differences was done to differentiate basal from apical dendrites in the same neuron. On average, ETP69-treated mice had 45\% more total number of spines per length of apical dendrite (microns) compared with controls Analysis of apical spine density by morphology revealed a significantly higher density of thin ( $p<0.001$, Student's $t$ test $)$ and stubby spines ( $p<0.05$, Student's $t$ test), in ETP69-treated mice compared with control mice (Fig. $8 a$ ). There was no difference in the numbers of mushroom spines/length of dendrite measured (Fig. 8a). In contrast, spines on basal dendrites showed no differences between groups. $t$ test comparisons between drug- and vehicle-treated groups showed the following $p$ values for thin spines is 0.82 , for stubby spines is 0.83 , and for mushroom spines is 0.95 (data not graphed).

Next, we studied the influence of ETP69 on synapses using flow synaptometry (Prieto et al., 2015), an innovative approach to molecularly characterize isolated synaptosomes (presynaptic terminals attached to postsynaptic dendritic spines) (Wilhelm et al., 2014). Specifically, we quantified the levels of PSD95 (scaffolding protein) and GluR1 (subunit of AMPA receptors), as the activity-dependent incorporation of AMPA receptor at PSDenriched regions promotes spine growth and increases synaptic transmission efficiency (Zhang et al., 2015a). After mice treatment, hippocampal synaptosome fractions were immunostained and analyzed by flow synaptometry, which first identifies synaptosomes by size using calibrated beads, as previously described (Prieto et al., 2015). We have previously shown that the subset of particles between 0.5 and $3.0 \mu \mathrm{m}$ is highly enriched in synaptosomes, as indicated by the high levels of synaptophysin and PSD95 in most (>70\%) size-gated particles (Prieto et al., 2015). Consistent with the ETP69-induced increase in spine numbers (Fig. 8a), our analysis on size-gated synaptosomes revealed that ETP69 increases the proportion of particles with detectable levels 

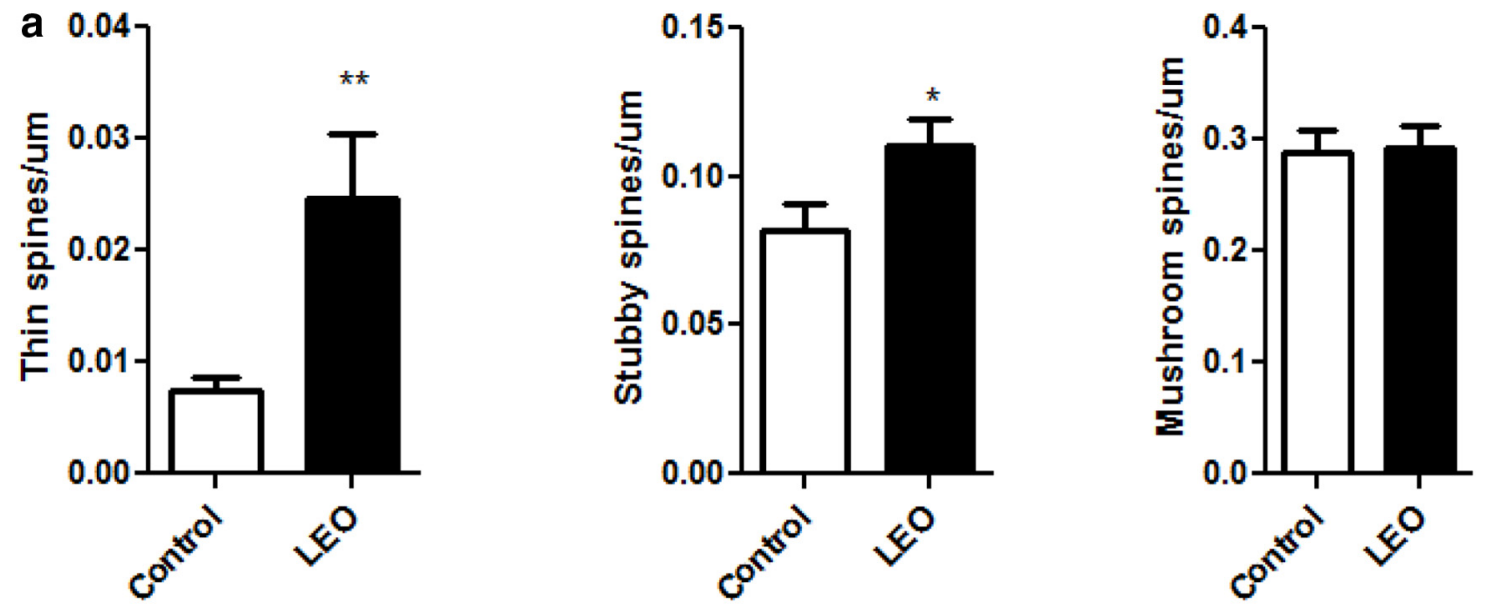

b

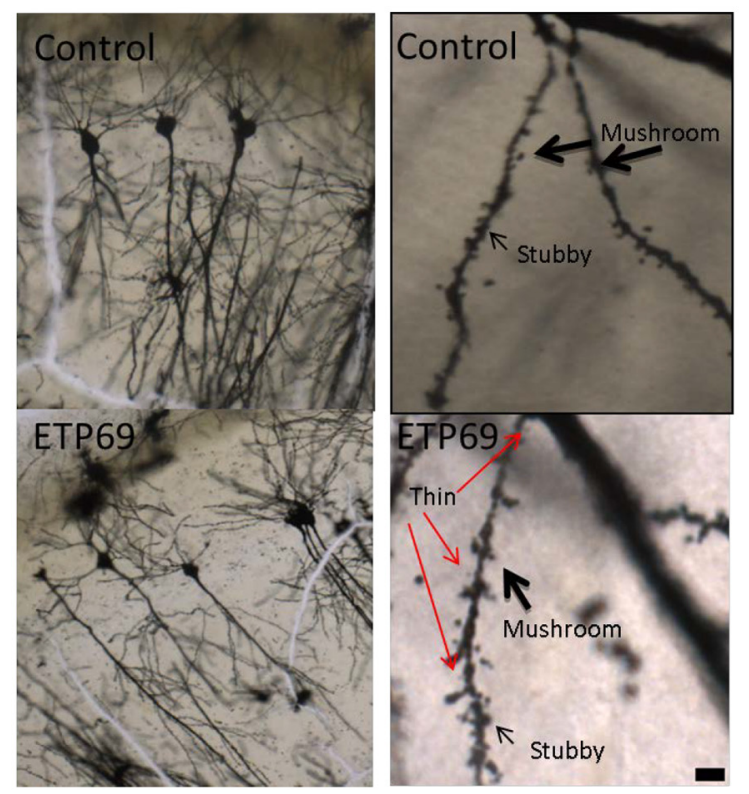

Figure 8. $\boldsymbol{a}$, Effect of ETP69 treatment on spine counts (thin, mushroom, and stubby) in the CA1 region of the hippocampus ${ }^{*} p<0.05$, significantly different compared with age-matched controls (Student's unpaired $t$ test). ${ }^{* *} p<0.01$, significantly different compared with age-matched controls (Student's unpaired $t$ test). $\boldsymbol{b}$, Representative images showing effect of ETP69 treatment on spines in the CA1 of the hippocampus. Top, Hippocampal neurons from control animals. Bottom, Spines observed in ETP69-treated animals.

of PSD95 ( $p<0.05$; Fig. $9 c$ ), thus reflecting an increase in the number of synapses. No changes were observed in the PSD95 levels per particle, as determined by the mean fluorescence of intensity. Next, to test whether ETP69 increases the relative levels of spines expressing surface GluR1, we quantified the proportion of size-gated synaptosomes coexpressing GluR1 at surface and PSD95 intracellularly by double labeling combining extracelullar (no permeabilization) and intracellular immunodetection. We found an increase in the percentage of GluR1-PSD95 doublepositive $\left(\right.$ GluR $1{ }^{+}$PSD95 ${ }^{+}$) events in ETP69-treated mice, compared with vehicle-treated controls ( $p=0.05$; Fig. $9 e$ ).

Synaptic plasticity depends on intracellular signaling and trafficking. In particular, the activation of the serine/threonine kinase Akt is an essential step for the activity-dependent transport of PSD95 to dendrites after NMDA receptor activation (Yoshii and Constantine-Paton, 2010). Therefore, we next analyzed the effects of ETP69 on Akt activation (phosphorylation at Serine473, pAkt) at the synapse by flow synaptometry. According to the increased proportion of PSD $95{ }^{+}$GluR $1{ }^{+}$events after ETP69 treatment, SUV39H1 inhibition by ETP69 also increased the proportion of $\mathrm{pAkt}^{+} \mathrm{PSD} 5^{+}$events, relative to samples from vehicle-treated mice $(p<0.05$; Fig. $9 g)$. Overall, these results suggest that $\mathrm{H} 3 \mathrm{~K} 9 \mathrm{me} 3$ inhibition acts, at least in part, by positively modulating molecular processes that promote spine generation and/or stability.

\section{ETP69 increases $\mathrm{H} 3 \mathrm{~K} 9 \mathrm{me} 3$ levels at BDNF promoter and BDNF protein levels in hippocampus of aged mice}

It stands to reason that, whether treatment with SUV39H1 inhibitor stimulates spine formation in the hippocampus, it should also produce gene-specific changes in distinct signaling cascades that can serve learning and memory. In the adult brain, one such molecule, which plays a major role on synapse formation and plasticity, is BDNF (Park and Poo, 2013). Thus, we tested the effect of $\mathrm{H} 3 \mathrm{~K} 9 \mathrm{me} 3$ downregulation on BDNF protein levels, which is critical for consolidation of hippocampal-dependent learning and memory (Intlekofer et al., 2013). The bdnf gene is composed of several noncoding exons, each one regulated by its own promoter and responding to different stimuli (Aid et al., 2007). We therefore evaluated whether ETP69 treatment de- 


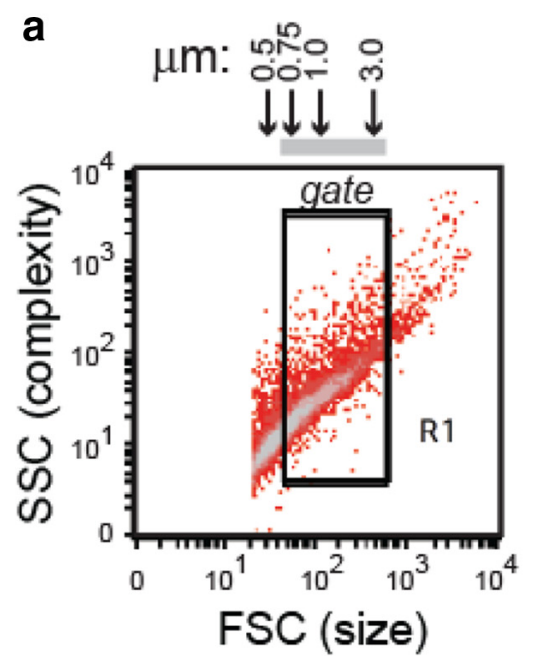

d
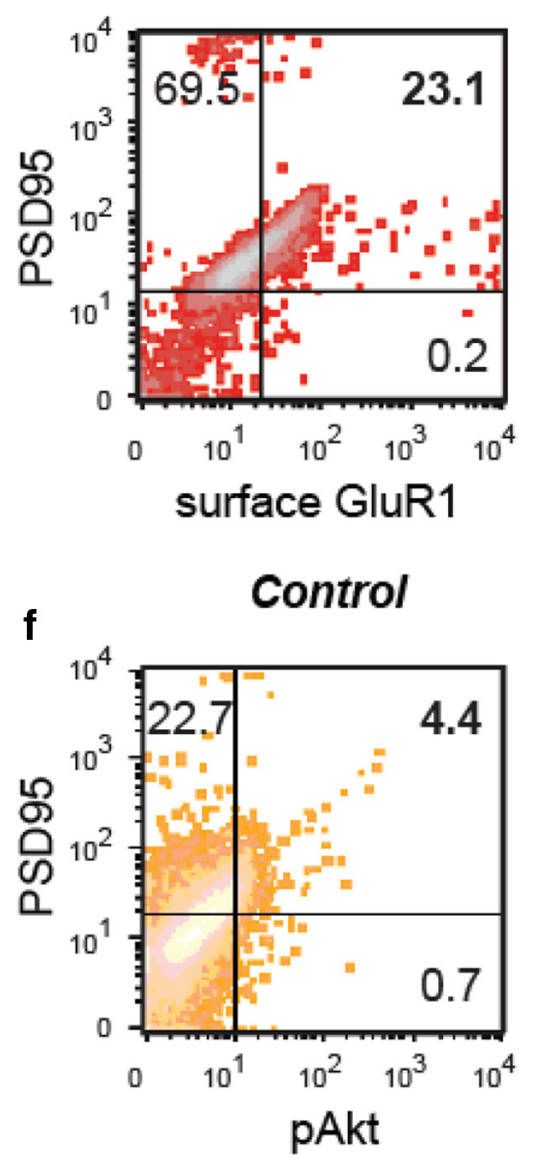

b staining controls:

- Control

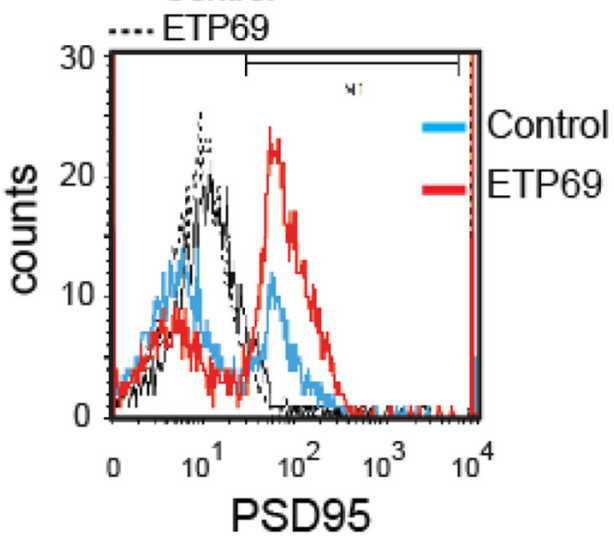

ETP69

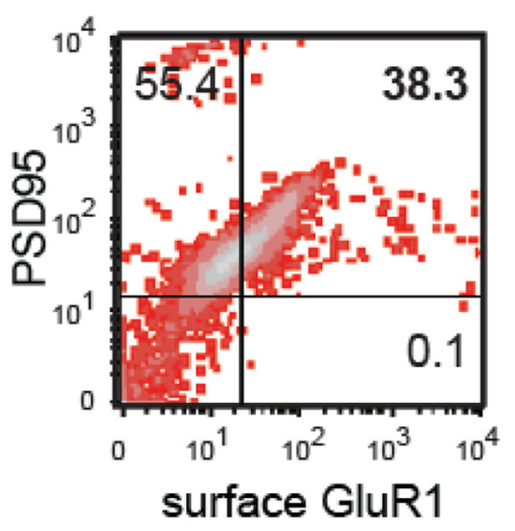

ETP69

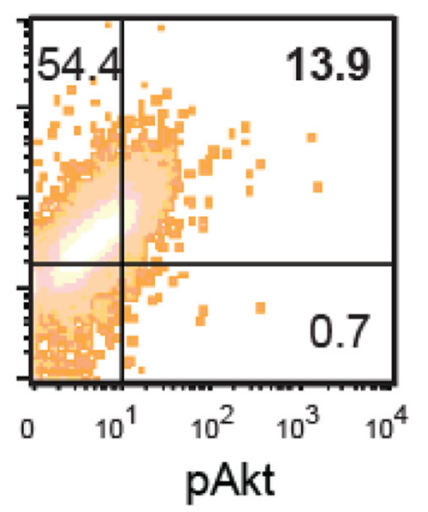

C

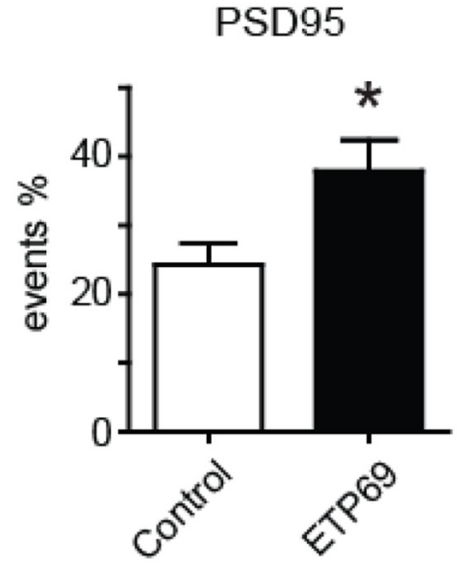

e

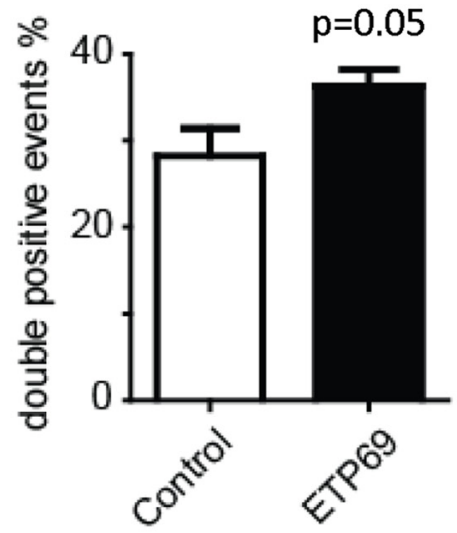

g

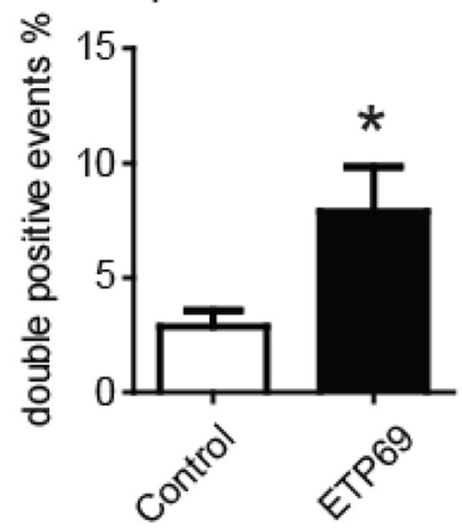

Figure 9. $\quad \boldsymbol{a}$, Representative density plot showing size-gated synaptosomes. $\boldsymbol{b}$, Representative histogram showing an increase in the PSD95-positive subpopulation of synaptosomes following ETP69 treatment. $c$, Percentage of PSD95-positive events increases following ETP69 treatment in synaptosomes obtained from aged mice. ${ }^{*} p<0.05$. $\boldsymbol{d}$, Representative density plots showing surface GluR1 and PSD95 expression in size-gated synaptosomes. $\boldsymbol{e}$, GluR1 and PSD95 double-positive events (top right quadrant) increase following ETP69 treatment in synaptosomes obtained from aged mice ( $p=0.05$, aged-treated vs aged control mice). $f$, Representative density plots showing pAkt and PSD95 detection in size-gated synaptosomes. pAkt and PSD95 double-positive events (top right quadrant) increase following ETP69 treatment. $\boldsymbol{g}$, Percentage of pAkt and PSD95 double-positive events increases following ETP69 treatment in synaptosomes obtained from aged mice ${ }^{*} p<0.05$ aged-treated vs aged control mice).

creases trimethylation of $\mathrm{H} 3 \mathrm{~K} 9$ at $b d n f$ Promoters I, IV, and VI. A significant effect of treatment was found for $\mathrm{H} 3 \mathrm{~K} 9 \mathrm{me} 3$ at $b d n f \mathrm{I}$ $(p=0.05$; Fig. 10b), but not $b d n f$ IV or VI. Therefore, exon I appears to be the main contributor to the differential regulation of pan-BDNF levels observed following acute ETP69 treatment. Importantly, ETP69-induced epigenetic changes at BDNF promoter were associated with an increase of BDNF protein levels in hippocampus. We found significantly elevated levels of BDNF in 
the hippocampus of ETP69-treated mice relative to controls $\left(F_{(2,16)}=8.09, p<\right.$ 0.01; Fig. 10a).

\section{Discussion}

In this study, we tested the potential of acute in vivo SUV39H1 inhibition and the consequent H3K9me3 downregulation to attenuate learning and memory deficits in aging. We further evaluated potential mechanisms that may contribute to cognitive benefits observed following H3K9me3 manipulation. Our findings show that performance of aged animals was improved in the object location memory task and the unsupervised learning task following SUV39H1 inhibition. This corresponded with an increase in dendritic spine density of pyramidal neurons and an increase in active synapses expressing GluR1-containing AMPA receptors in the hippocampus, along with increased levels of pAkt in synaptosomal extracts obtained from the hippocampi of these animals. Levels of BDNF were also upregulated in the hippocampus of animals, which had been administered the SUV39H1 inhibitor. These results, therefore, provide support for the amelioration of cognitive deficits and suggest that SUV39H1 inhibition and likely the resulting H3K9me3 downregulation trigger a cascade of events involving $\mathrm{BDNF}$, spine remodeling, and growth.

To the best of our knowledge, there have been no studies that have evaluated the effect of $\mathrm{H} 3 \mathrm{~K} 9 \mathrm{me} 3$ inhibition on learning and/or memory function. Here, we present the first evidence that decreased $\mathrm{H} 3 \mathrm{~K} 9 \mathrm{me} 3$ in the hippocampus improves spatial memory in aged mice but not in young mice. This is an important finding in that histone deacetylase inhibition, which is a well-characterized epigenetic mechanism underlying synaptic plasticity and memory, is known to improve performance in even young animals (Stefanko et al., 2009). In our experiments in both pretraining and posttraining paradigms of the OLM task, ETP69-treated aged (but not young) animals performed equally well during testing, $24 \mathrm{~h}$ after the acquisition trial. This led us to believe that acute treatment with ETP69 was inducing a hippocampus-specific change in $\mathrm{H} 3 \mathrm{~K} 9 \mathrm{me} 3$ levels in aged animals. Our data from the USL task confirmed that ETP69-treated animals were showing improved retention and recall at $24 \mathrm{~h}$ but not at $30 \mathrm{~min}$ after drug treatment, when learning remained the same between groups. Repressors and cofactors recruited by H3K9me3 include histone deacetylases and heterochromatin protein- $1 \alpha$. Indeed, heterochromatin protein- $1 \alpha$ associates directly with SUV39H1 and leads to a self-sustaining repressive cycle (Lund and van Lohuizen, 2004) and may require $>30$ min to show any behavioral manifestations. Thus, our findings are consistent with the hypothesis that changes at the molecular (and hence behavioral levels) are not rapidly engaged but need time to evolve the mechanism supporting improved retention and recall.

Transient increases in spine density have been associated with improved learning and memory, particularly in the hippocampus of aged mice (deToledo-Morrell et al., 1988; von Bohlen und Halbach et al., 2006), but the effect of H3K9me3 manipulation on synaptic function and spines is currently un- explored. Here we report that ETP69 increased both thin and stubby spine count in the CA1 region of ETP69-treated animals. Thin spines are flexible and critical for formation of new synapses, which makes them well suited for facilitating acute improvements in cognition observed with ETP69 treatment. Our data suggest that the drug engages mechanisms that support spine plasticity and growth. We also found increases in levels of both $\mathrm{PSD}^{+}$synaptosomes and the PSD95 ${ }^{+}$synaptosomes expressing surface GluR1 in synaptic terminals Previously, it has been demonstrated that remodeling spines requires incorporation of AMPA receptor at PSD-enriched regions (Park et al., 2004). It is also known that synaptic connections can be strengthened by addition of AMPA receptor to synapses (Lee and Kirkwood, 2011; Huganir and Nicoll, 2013). Thus, our data support the hypothesis that $\mathrm{H} 3 \mathrm{~K} 9$ me 3 mediates changes to synaptic signaling in the hippocampus leading to improved cognitive function in aging.

BDNF is a key molecule serving synaptic plasticity and neuronal activity. We have previously shown that histone deacetylase inhibition in the aged brain improves spatial memory in a BDNF-dependent manner (Intlekofer et al., 2013). Because histone deacetylase is one of the cofactors recruited by $\mathrm{H} 3 \mathrm{~K} 9 \mathrm{me} 3$, we tested the role of SUV39H1 inhibition on BDNF protein levels in the aged brain. Our data show that $\mathrm{H} 3 \mathrm{~K} 9 \mathrm{me} 3$ modulates learning and memory, and it is likely that this effect is mediated by a BDNF-dependent mechanism. Our results suggest that it is primarily Promoter I that drives BDNF upregulation following ETP69 treatment in aged mice. It appears likely that $\mathrm{H} 3 \mathrm{~K} 9 \mathrm{me} 3$ inhibition selectively participates in regulation of BDNF Promoter I, but the downstream result of this selectivity remains unknown. We would also like to point out that systemic drug treatment (as in this study) will reduce $\mathrm{H} 3 \mathrm{~K} 9 \mathrm{me} 3$-mediated transcriptional repression across multiple genes, not only BDNF but likely transcripts that support or suppress plasticity. Further studies are warranted to evaluate these regulatory mechanisms.

In conclusion, this study provides a first look at the cascade of possibilities regulated either directly or indirectly by $\mathrm{H} 3 \mathrm{~K} 9 \mathrm{me} 3$ downregulation. It is possible that activation of certain molecular pathway following removal of the $\mathrm{H} 3 \mathrm{~K} 9 \mathrm{me} 3$ repressive mark activates hippocampal-memory pathway(s), 
which in turn may generate additional transcription and translation required for the maintenance of improved memory function in aged animals. Finally, this study provides support to the hypothesis that, by manipulating the enzyme that regulates histone methylation, it is possible to alter the chromatin state of subjects and restore memory function in the aging brain.

\section{References}

Aid T, Kazantseva A, Piirsoo M, Palm K, Timmusk T (2007) Mouse and rat BDNF gene structure and expression revisited. J Neurosci Res 85: 525-535. CrossRef Medline

Babayan AH, Kramár EA, Barrett RM, Jafari M, Häettig J, Chen LY, Rex CS, Lauterborn JC, Wood MA, Gall CM, Lynch G (2012) Integrin dynamics produce a delayed stage of long-term potentiation and memory consolidation. J Neurosci 32:12854-12861. CrossRef Medline

Bachevalier J, Nemanic S (2008) Memory for spatial location and objectplace associations are differently processed by the hippocampal formation, parahippocampal areas TH/TF and perirhinal cortex. Hippocampus 18:64-80. CrossRef Medline

Balemans MC, Kasri NN, Kopanitsa MV, Afinowi NO, Ramakers G, Peters TA, Beynon AJ, Janssen SM, van Summeren RC, Eeftens JM, Eikelenboom N, Benevento M, Tachibana M, Shinkai Y, Kleefstra T, van Bokhoven H, Van der Zee CE (2013) Hippocampal dysfunction in the Euchromatin histone methyltransferase 1 heterozygous knockout mouse model for Kleefstra syndrome. Hum Mol Genet 22:852-866. CrossRef Medline

Baumann M, Dieskau AP, Loertscher BM, Walton MC, Nam S, Xie J, Horne D, Overman LE (2015) Tricyclic analogues of epidithiodioxopiperazine alkaloids with promising in vitro and in vivo antitumor activity. Chem Sci 6:4451-4457. CrossRef Medline

Chen LY, Rex CS, Sanaiha Y, Lynch G, Gall CM (2010a) Learning induces neurotrophin signaling at hippocampal synapses. Proc Natl Acad Sci U S A 107:7030-7035. CrossRef Medline

Chen LY, Rex CS, Pham DT, Lynch G, Gall CM (2010b) BDNF signaling during learning is regionally differentiated within hippocampus. J Neurosci 30:15097-15101. CrossRef Medline

Cherblanc FL, Chapman KL, Brown R, Fuchter MJ (2013) Chaetocin is a nonspecific inhibitor of histone lysine methyltransferases. Nat Chem Biol 9:136-137. CrossRef Medline

Cox CD, Rex CS, Palmer LC, Babayan AH, Pham DT, Corwin SD, Trieu BH, Gall CM, Lynch G (2014) A map of LTP-related synaptic changes in dorsal hippocampus following unsupervised learning. J Neurosci 34: 3033-3041. CrossRef Medline

deToledo-Morrell L, Geinisman Y, Morrell F (1988) Age-dependent alterations in hippocampal synaptic plasticity: relation to memory disorders. Neurobiol Aging 9:581-590. CrossRef Medline

Duva CA, Floresco SB, Wunderlich GR, Lao TL, Pinel JP, Phillips AG (1997) Disruption of spatial but not object-recognition memory by neurotoxic lesions of the dorsal hippocampus in rats. Behav Neurosci 111:1184-1196. CrossRef Medline

Fedulov V, Rex CS, Simmons DA, Palmer L, Gall CM, Lynch G (2007) Evidence that long-term potentiation occurs within individual hippocampal synapses during learning. J Neurosci 27:8031-8039. CrossRef Medline

Fein JA, Sokolow S, Miller CA, Vinters HV, Yang F, Cole GM, Gylys KH (2008) Co-localization of amyloid beta and tau pathology in Alzheimer's disease synaptosomes. Am J Pathol 172:1683-1692. CrossRef Medline

Gräff J, Rei D, Guan JS, Wang WY, Seo J, Hennig KM, Nieland TJ, Fass DM, Kao PF, Kahn M, Su SC, Samiei A, Joseph N, Haggarty SJ, Delalle I, Tsai LH (2012) An epigenetic blockade of cognitive functions in the neurodegenerating brain. Nature 483:222-226. CrossRef Medline

Greiner D, Bonaldi T, Eskeland R, Roemer E, Imhof A (2005) Identification of a specific inhibitor of the histone methyltransferase SU(VAR)3-9. Nat Chem Biol 1:143-145. CrossRef Medline

Gupta S, Kim SY, Artis S, Molfese DL, Schumacher A, Sweatt JD, Paylor RE, Lubin FD (2010) Histone methylation regulates memory formation. J Neurosci 30:3589-3599. CrossRef Medline

Haettig J, Stefanko DP, Multani ML, Figueroa DX, McQuown SC, Wood MA (2011) HDAC inhibition modulates hippocampus-dependent longterm memory for object location in a CBP-dependent manner. Learn Mem 18:71-79. CrossRef Medline
Harris KM, Jensen FE, Tsao B (1992) Three-dimensional structure of dendritic spines and synapses in rat hippocampus (CA1) at postnatal day 15 and adult ages: implications for the maturation of synaptic physiology and long-term potentiation. J Neurosci 12:2685-2705. Medline

Huganir RL, Nicoll RA (2013) AMPARs and synaptic plasticity: the last 25 years. Neuron 80:704-717. CrossRef Medline

Intlekofer KA, Berchtold NC, Malvaez M, Carlos AJ, McQuown SC, Cunningham MJ, Wood MA, Cotman CW (2013) Exercise and sodium butyrate transform a subthreshold learning event into long-term memory via a brain-derived neurotrophic factor-dependent mechanism. Neuropsychopharmacology 38:2027-2034. CrossRef Medline

Jarome TJ, Lubin FD (2014) Epigenetic mechanisms of memory formation and reconsolidation. Neurobiol Learn Mem 115:116-127. CrossRef Medline

Lee HK, Kirkwood A (2011) AMPA receptor regulation during synaptic plasticity in hippocampus and neocortex. Semin Cell Dev Biol 22: 514-520. CrossRef Medline

Lund AH, van Lohuizen M (2004) Epigenetics and cancer. Genes Dev 18: 2315-2335. CrossRef Medline

Mai A, Rotili D, Valente S, Kazantsev AG (2009) Histone deacetylase inhibitors and neurodegenerative disorders: holding the promise. Curr Pharm Des 15:3940-3957. CrossRef Medline

Morse SJ, Butler AA, Davis RL, Soller IJ, Lubin FD (2015) Environmental enrichment reverses histone methylation changes in the aged hippocampus and restores age-related memory deficits. Biology (Basel) 4:298-313. CrossRef Medline

Overman LE, Baumann M, Nam S, Horne D, Jove R, Xie J, Kwolik C (2014) Preparation of epipolythiodioxopiperazine ETP derivatives for treatment of cancer. PCT Int App. WO2014066435, A1.

Park H, Poo MM (2013) Neurotrophin regulation of neural circuit development and function. Nat Rev Neurosci 14:7-23. CrossRef Medline

Park M, Penick EC, Edwards JG, Kauer JA, Ehlers MD (2004) Recycling endosomes supply AMPA receptors for LTP. Science 305:1972-1975. CrossRef Medline

Prieto GA, Snigdha S, Baglietto-Vargas D, Smith ED, Berchtold NC, Tong L, Ajami D, LaFerla FM, Rebek J Jr, Cotman CW (2015) Synapse-specific IL-1 receptor subunit reconfiguration augments vulnerability to IL- $1 \beta$ in the aged hippocampus. Proc Natl Acad Sci U S A 112:E5078-E5087. CrossRef Medline

Restivo L, Vetere G, Bontempi B, Ammassari-Teule M (2009) The formation of recent and remote memory is associated with time-dependent formation of dendritic spines in the hippocampus and anterior cingulate cortex. J Neurosci 29:8206-8214. CrossRef Medline

Sahar S, Reddy MA, Wong C, Meng L, Wang M, Natarajan R (2007) Cooperation of SRC-1 and p300 with NF-kappaB and CREB in angiotensin II-induced IL-6 expression in vascular smooth muscle cells. Arterioscler Thromb Vasc Biol 27:1528-1534. CrossRef Medline

Sandoval ME, Horch P, Cotman CW (1978) Evaluation of glutamate as a hippocampal neurotransmitter: glutamate uptake and release from synaptosomes. Brain Res 142:285-299. CrossRef Medline

Sedivy JM, Banumathy G, Adams PD (2008) Aging by epigenetics: a consequence of chromatin damage? Exp Cell Res 314:1909-1917. CrossRef Medline

Snigdha S, Idris N, Grayson B, Shahid M, Neill JC (2011) Asenapine improves phencyclidine-induced object recognition deficits in the rat: evidence for engagement of a dopamine D1 receptor mechanism. Psychopharmacology 214:843-853. CrossRef Medline

Stefanko DP, Barrett RM, Ly AR, Reolon GK, Wood MA (2009) Modulation of long-term memory for object recognition via HDAC inhibition. Proc Natl Acad Sci U S A 106:9447-9452. CrossRef Medline

Stewart MD, Li J, Wong J (2005) Relationship between histone H3 lysine 9 methylation, transcription repression, and heterochromatin protein 1 recruitment. Mol Cell Biol 25:2525-2538. CrossRef Medline

Vakoc CR, Sachdeva MM, Wang H, Blobel GA (2006) Profile of histone lysine methylation across transcribed mammalian chromatin. Mol Cell Biol 26:9185-9195. CrossRef Medline

Villeneuve LM, Reddy MA, Lanting LL, Wang M, Meng L, Natarajan R (2008) Epigenetic histone H3 lysine 9 methylation in metabolic memory and inflammatory phenotype of vascular smooth muscle cells in diabetes. Proc Natl Acad Sci U S A 105:9047-9052. CrossRef Medline 
Villeneuve LM, Kato M, Reddy MA, Wang M, Lanting L, Natarajan R (2010) Enhanced levels of microRNA-125b in vascular smooth muscle cells of diabetic $\mathrm{db} / \mathrm{db}$ mice lead to increased inflammatory gene expression by targeting the histone methyltransferase Suv39h1. Diabetes 59:2904-2915. CrossRef Medline

von Bohlen und Halbach O, Zacher C, Gass P, Unsicker K (2006) Agerelated alterations in hippocampal spines and deficiencies in spatial memory in mice. J Neurosci Res 83:525-531. CrossRef Medline

Wilhelm BG, Mandad S, Truckenbrodt S, Kröhnert K, Schäfer C, Rammner B, Koo SJ, Claßen GA, Krauss M, Haucke V, Urlaub H, Rizzoli SO (2014) Composition of isolated synaptic boutons reveals the amounts of vesicle trafficking proteins. Science 344:1023-1028. CrossRef Medline
Yoshii A, Constantine-Paton M (2010) Postsynaptic BDNF-TrkB signaling in synapse maturation, plasticity, and disease. Dev Neurobiol 70: 304-322. CrossRef Medline

Zhang L, Hsu FC, Mojsilovic-Petrovic J, Jablonski AM, Zhai J, Coulter DA, Kalb RG (2015a) Structure-function analysis of SAP97, a modular scaffolding protein that drives dendrite growth. Mol Cell Neurosci 65:31-44. CrossRef Medline

Zhang W, Li J, Suzuki K, Qu J, Wang P, Zhou J, Liu X, Ren R, Xu X, Ocampo A, Yuan T, Yang J, Li Y, Shi L, Guan D, Pan H, Duan S, Ding Z, Li M, Yi F, et al. (2015b) Aging stem cells: a Werner syndrome stem cell model unveils heterochromatin alterations as a driver of human aging. Science 348:1160-1163. CrossRef Medline 